\title{
DAYA TAHAN BAITUL MAL WAT TAMWIL DALAM ARUS REVOLUSI INDUSTRI 4.0
}

\author{
Eja Armaz Hardi \\ UIN Sulthan Thaha Saifuddin Jambi \\ eja.armaz.hardi@gmail.com
}

\begin{abstract}
Abstrak - Artikel ini bertujuan untuk menganalisa ketahanan Baitul Mal wat Tamwil (BMT) di dalam arus revolusi industri 4.0 pada bidang financial technology (fintech). BMT merupakan salah satu Lembaga Keuangan Mikro Syariah (LKMS) di Indonesia yang memiliki segmentasi konsumen spesifik yaitu masyarakat low-middle income dan tidak memiliki akses kepada perbankan (unbankable). BMT terbukti memiliki peran signifikan dalam membantu mengurangi tingkat kemiskinan di Indonesia dengan program pemberdayaan yang dimilikinya. Di saat bersamaan, proses manajemen yang berlaku pada BMT masih relatif berbelit dan panjang, seperti pendampingan pra-pembiayaan, proses pembiayaan dan pasca pembiayaan. Akan tetapi, satu dekade terakhir, perkembangan teknologi finansial (fintech) melakukan inovasi yang signifikan dalam bidang industri keuangan. Salah satu signifikansi dari inovasi fintech adalah mendistrupsi atau memotong jalur panjang administrasi yang berlaku selama di lembaga keuangan. Di samping itu ia juga menawarkan kecepatan, mobilitas dan akurasi proses transaksi keuangan masyarakat. Dengan menggunakan analisis deskriptif kualitatif, artikel ini menemukan bahwa, walaupun fintech menawarkan inovasi yang distrubtif dalam transaksi keuangan saat ini, BMT cenderung akan tetap bertahan dengan distingsi dan segmentasi yang dimilikinya. Akan tetapi, resistensi tersebut menjadi berbeda ketika penduduk Indonesia yang berusia di atas 65 tahun saat ini disubstitusi oleh generasi milenial pada tahun 2035. Oleh karena itu, artikel ini merekomendasikan bahwa untuk menghindari penurunan peran dalam membantu masyarakat menengah ke bawah dalam hal finansial, BMT harus menyesuaikan diri dengan melakukan inovasi, integrasi, interkoneksi dengan perusahaan fintech.
\end{abstract}

Kata Kunci: BMT, Lembaga Keuangan Mikro Syariah, Revolusi Industri 4.0, Fintech

Abstract - This article aims to analyze the resilience of the Baitul Mal wat Tamwil (BMT) in the era of industrial revolution 4.0 in the field of financial technology (fintech). BMT is one of the Sharia Microfinance Institutions (LKMS) in Indonesia has specific consumer segmentation, namely low-middle income people and no access to banks (un-bankable). BMT has proven to have a significant role in helping to reduce poverty levels in Indonesia with its empowerment program. At the same time, the management processes that apply to BMTs are still relatively complicated and long, such as pre-financing assistance, financing processes and post-financing. However, in the last decade, the development of fin-tech has made significant innovations in the financial industry. One significance of fin-tech innovation is the distribution or cutting of the long administrative path that applies while at a financial institution. In 
addition, he also offers the speed, mobility and accuracy of the public financial transaction process. Using a qualitative descriptive analysis, this article finds that, although fin-tech offers constructive innovation in current financial transactions, BMTs will tend to survive with their distinction and segmentation. However, this resistance becomes different when the Indonesian population aged over 65 years would substituted by millennial generation in 2035. Therefore, this article recommends that in order to avoid reducing its role in helping the middle to lower financially, the BMT must adjust to innovation, integration, interconnection with fintech companies.

Keywords: BMT, Shariah Microfinance Institutions, Industrial Revolution 4.0, Fintech

\section{PENDAHULUAN}

Dalam kurun waktu 17 tahun jumlah penduduk Indonesia menurut Badan Pusat Statistik (BPS) tumbuh secara eksponensial dari 213.4 juta jiwa pada tahun 2000 menjadi 264 juta jiwa pada tahun 2017. Di samping itu, jumlah kemiskinan menunjukkan gejala sebaliknya dengan mengalami penurunan secara signifikan dari 47.97 juta jiwa atau berkisar 23.43 persen pada tahun 1999 menjadi 26.58 juta jiwa atau sekitar 10.28 persen dari total penduduk per September 2017 (Badan Pusat Statistik, 2018). Dilain pihak, Indonesia mengalami pertumbuhan yang cukup signifikan pada aspek pendapatan per kapita, tercatat oleh Bank Dunia pada tahun 2000 pendapatan per kapita penduduk Indonesia 5,805.81 USD meningkat menjadi $10,764.55$ USD pada tahun 2016, (lihat tabel 01).

Tabel 1. Pertumbuhan Penduduk, Tingkat Kemiskinan, dan Pendapatan Perkapita Indonesia Periode (2000-2017) (juta jiwa) (persen/\%)

\begin{tabular}{|c|c|c|c|c|c|}
\hline Items/Tahun & $\mathbf{2 0 0 0}$ & $\%$ & $\mathbf{2 0 1 7}$ & $\%$ & $\begin{array}{c}\text { Growth } \\
(\%)\end{array}$ \\
\hline Penduduk & 213.40 & & 264 & & 23.71 \\
\hline Kemiskinan & 47.97 & 23.43 & 26.72 & 10.12 & -44.30 \\
\hline $\begin{array}{c}\text { Pendapatan } \\
\text { Perkapita }\end{array}$ & $5,805,81$ & & $10,764.55$ & & 85.41 \\
\hline \\
Sumber: Data diolah dari: www.bps. go.id dan www.worldbank.org \\
\hline
\end{tabular}

Informasi pada tabel 01 menunjukkan bahwa, pertumbuhan jumlah penduduk Indonesia sebesar 23.71 persen tersebut menyebabkan penurunan angka kemiskinan mencapai dua kali lipat yaitu -44.30 persen. Akan tetapi, penurunan angka kemiskinan tersebut masih jauh tertinggal dari pertumbuhan pendapatan per kapita sebanyak dua kali lipat dari penurunan angka kemiskinan atau mencapai 85.41 persen dalam kurun waktu 18 tahun. Hal ini mengindikasikan bahwa, pertumbuhan perekonomian yang signifikan pada jangka panjang tidak diiringi secara baik penurunan angka kemiskinan.

Apabila mengacu kepada standar kemiskinan yang ditetapkan oleh Bank Dunia sebesar 1.25 USD atau Rp17.500 (kurs Rp14,000) per hari untuk menentukan penduduk miskin, maka jumlah penduduk miskin di Indonesia cenderung lebih kecil dari angka yang dirilis oleh BPS, yaitu 6.5 persen atau 16.97 juta jiwa dari total penduduk 261.1 juta jiwa pada tahun 2016. Akan tetapi, standar tersebut cenderung tidak dapat dijadikan tolak ukur secara logis bagi seorang manusia. Mengapa demikian? Karena dengan standar kemiskinan dihitung dengan 1.25 USD per hari, maka akan muncul angka pendapatan sebesar Rp525,000 per-bulan atau Rp17,500 per-hari (kurs Rp14,000).

Dari data yang dipaparkan sebelumnya, pertumbuhan pendapatan 
per kapita Indonesia yang diiringi dengan penurunan jumlah kemiskinan menyisakan beberapa masalah sosial. Permasalahan ini dikarenakan pertumbuhan tersebut tidak disertai dengan menurunnya kesenjangan pendapatan. Disaat yang bersamaan, pertumbuhan pendapatan orang-orang terkaya lebih besar dibanding orangorang miskin sehingga orang terkaya dapat menikmati pertumbuhan pembangunan dengan porsi yang sangat besar dan melahirkan tren kesenjangan pendapatan (Hasanah \& Yusuf, 2013). Hal demikian tentu menjadi paradoks ketika Indonesia disebut sebagai negara yang memiliki demografi muslim terbesar di Dunia, disisi lain mayoritas penduduk miskinnya adalah masyarakat muslim. Oleh karena itu, permasalahan kemiskinan mendapat perhatian serius pemerintah. Terlebih permasalahan kemiskinan menjadi salah satu dari 17 tujuan utama Sustainable Development Goals (SDGs).

Salah satu upaya yang dapat dilakukan untuk memutus mata rantai kemiskinan adalah sebagaimana diungkapkan oleh Amalia (2009) dalam artikel Adnan yang menyatakan bahwa salah satu perangkat yang paling efektif dalam memutus mata rantai kemiskinan adalah pemberdayaan dengan kredit mikro melalui lembaga keuangan mikro (MFIs) (Adnan \& Ajija, 2015). Hal ini dikarenakan lembaga keuangan mikro berbentuk koperasi merupakan sistem keuangan dapat bergerak dalam lingkup terkecil dalam sistem perekonomian negara dan berkembang secara konsisten pada model kredit pertanian, keuangan, konsumen, dan koperasi serba usaha (M. Dawam Rahardjo, 2015). Kemudian dari temuan di lapangan menunjukkan bahwa, program dan manajemen yang di lakukan Baitul Mal wat Tamwil (BMT) Madrasah Muftahul 'Ulum (MMU) Sidogiri dalam mengurangi tingkat kemiskinan secara signifikan (Adnan \& Ajija, 2015). Selanjutnya, berkaitan dengan pemberdayaan, penelitian di Baitul Mal BMT Beringharjo Yogyakarta juga menunjukkan adanya peningkatan pendapatan bagi masyarakat muslim miskin yang memanfaatkan fasilitas qard\}ul al-h\}asan (Hardi, 2013).

Signifikansi temuan dari penelitian sebelumnya tidak lepas dari daya adaptasi lembaga keuangan mikro yang tinggi dalam merespons masyarakat kelas bawah yang dinamis. Oleh karena itu, lembaga keuangan mikro hadir untuk merespons kebutuhan akses keuangan kelompok usaha mikro dan masyarakat lapisan bawah yang secara teknis sulit untuk mengakses lembaga keuangan formal terutama dalam memperoleh dukungan kredit atau pembiayaan (Indonesia, n.d.). Menurut laporan tahun yang dirilis oleh Otoritas Jasa Keuangan (OJK) Indonesia menunjukkan bahwa jumlah Lembaga Keuangan Mikro (LKM) dan Lembaga Keuangan Mikro Syariah (LKMS) di Indonesia mengalami peningkatan jumlah kantor dan aset yang signifikan dalam tiga tahun terakhir, sebagaimana terlihat pada tabel 02 berikut:

Tabel 2. Pertumbuhan Jumlah dan Aset Lembaga Keuangan Mikro Konvensional dan Syariah yang Terdaftar di Otoritas Jasa Keuangan (OJK)

( ${ }^{*}$ juta rupiah)

\begin{tabular}{|c|c|c|c|}
\hline LKM & 2018 & 2017 & 2016 \\
\hline Konvensional & 123 & 151 & 119 \\
\hline Koperasi & 101 & 132 & 99 \\
\hline PT & 22 & 19 & 17 \\
\hline Syariah & 60 & 29 & 13 \\
\hline Koperasi & 59 & 29 & 13 \\
\hline PT & 1 & - & - \\
\hline Total & 183 & 180 & 129 \\
\hline Aset ${ }^{*}$ & 748,34 & 446,75 & 283,84 \\
\hline
\end{tabular}

Akan tetapi, perkembangan jumlah entitas dan aset LKM dan LKMS tersebut diiringi dengan pertumbuhan sektor teknologi keuangan (financial technology. fintech). Jumlah fintech 
Lending yang terdaftar di OJK per Januari 2019 mencapai 99 perusahaan, jumlah tersebut jauh lebih kecil dari jumlah fintech yang beredar. Di samping itu juga, pertumbuhan toko digital (ecommerce) dan dompet digital saat ini mengalami peningkatan yang eksponensial. Kemudian, perusahaanperusahaan fintech tersebut dapat menjangkau konsumen lebih banyak dalam waktu yang relatif singkat. Dari tiga e-commerce terbesar di Indonesia, Tokopedia, Buka Lapak dan Shopee, jumlah kunjungan pada aplikasi tersebut mencapai 168 juta, 116 juta, dan 67.7 juta pengunjung, sedangkan dari sisi pendanaan dan valuasi pasar Tokopedia menempati peringkat tertinggi yang mencapai 2.4 milyar USD pendanaan dan valuasi mencapai 7 milyar USD. Selain itu, dompet digital yang beredar di Indonesia mencapai akumulasi 21 triliun rupiah, sebagaimana terlihat pada tabel 03 berikut:

Tabel 3. Jumlah Akumulasi Pendanaan, Valuasi, dan Kunjungan pada perusahaan e-commerce, Dompet Digital dan Fintech Lending di Indonesia Triwulan III 2018

$\left({ }^{*} J u t a\right.$ Kalii ${ }^{* *}$ Milyar USD ${ }^{* * *}$ Triliun IDR/ ${ }^{* * * *}$ Juta USD)

\begin{tabular}{|r|c|c|c|c|c|}
\hline $\begin{array}{l}\text { e- } \\
\text { commerce }\end{array}$ & Kunjungan $^{\star}$ & Funding $^{\star \star}$ & Valuasi $^{\star \star}$ & $\begin{array}{c}\text { Akumulasi } \\
\text { dana }^{\star \star \star}\end{array}$ & Qn \\
\hline Tokopedia & 168 & 2.4 & 7 & & \\
\hline Buka Lapak & 116 & $50.1^{\star \star \star \star}$ & 1 & & \\
\hline Shopee & 67.7 & & & & \\
\hline Lazada & 58.3 & & & & \\
\hline Blibli & 43.1 & & & & \\
\hline Go-Jek & & 2.2 & 5 & & \\
\hline Traveloka & & $500^{\star \star \star \star}$ & 2 & & \\
\hline $\begin{array}{c}\text { Dompet } \\
\text { Digital }\end{array}$ & & & & 21 & \\
\hline $\begin{array}{c}\text { Fintech } \\
\text { Lending }\end{array}$ & & & & & 99 \\
\hline
\end{tabular}

Sumber: Data diolah dari: (Jasa Keuangan, 2019a) www.ojk.go.id dan ("Jumlah Akumulasi Pendanaan, Valuasi, Dan Kunjungan Pada Perusahaan e-Commerce," 2019) www.databoks.co.id

Perkembangan industri 4.0 saat ini menjadi sesuatu yang niscaya yang tidak dapat dihindari oleh siapa pun, termasuk penduduk Indonesia. Pertumbuhan ecommerce, dompet digital, dan fintech lending saat ini memangkas jalur distribusi perekonomian konvensional. Di samping itu, transaksi real time, cepat, dan dimanis menjadi salah satu distingsi revolusi industri 4.0 saat ini. Dengan demikian, dari beberapa isu yang disebutkan sebelumnya, apakah LKMS khususnya BMT yang selama ini berperan dan terbukti secara signifikan membantu masyarakat kelas bawah memperoleh akses keuangan dan membantu mengurangi tingkat kemiskinan dapat mempertahankan trahnya di tengah era disrupsi saat ini?. Untuk menjawab kegelisahan akademik tersebut, artikel ini pada bagian awal akan membahas secara komprehensif tentang LKMS dalam hal ini BMT, teknologi finansial, dan akan membahas segmentasi keuangan digital di tengah masyarakat Indonesia. Kemudian pembahasan hasil penelitian meliputi distingsi BMT dan ketahanan BMT dalam menghadapi era disrupsi saat ini. Pada bagian akhir, artikel ini menyajikan kesimpulan, rekomendasi kepada pihak terkait, dan ruang pengembangan penelitian selanjutnya di masa yang akan datang.

\section{KAJIAN LITERATUR}

\section{Baitul Mal wat Tamwil dan Segmentasinya}

Baitul Mal memainkan peran penting di awal masa kenabian Muhammad SAW. Keberadaan Baitul Mal berlanjut hingga masa kekhalifahan khulafa> ur al-ra>shidi>n dan khilafahkhilafah setelahnya. la menjadi pusat sirkulasi keluar masuk kas (cash flow) keuangan negara. Akan tetapi, peran Baitul Mal pada awal masa pemerintahan Nabi Muhammad SAW masih dalam lingkup sosial-ekonomi dan belum memiliki orientasi ekonomi-bisnis. Baitul Mal pertama memiliki fungsi sebagai lembaga negara terjadi pada tahun kedua pemerintahan khalifah Abu Bakar as-Sidq RA (Wardani \& Thoin, 2013). Sehingga peran sosial dan 
ekonomi Baitul Mal yang menjadi sakral pada masa itu. Hal tersebut tercermin dari distribusi hasil kekayaan negara berupa dana sosial karitas Islam, harta rampasan perang, pajak tanah dan hasil bumi dan lain sebagainya berjalan dengan baik dan disalurkan sepenuhnya untuk kepentingan masyarakat miskin dan membutuhkan. Dengan demikian, negara bertanggung jawab penuh terhadap kesejahteraan dan kemakmuran rakyat (Ayub, 2007; Benthall, 1999).

Dalam konteks Indonesia lembaga tersebut tidak hanya bergerak dalam bidang sosial-ekonomi akan tetapi juga bergerak pada bidang bisnis, yang kenal dengan Baitul Mal wat Tamwil (rumah harta dan bisnis/BMT) (Huda \& Heykal, 2010). Lahirnya BMT di Indonesia diinisiasi oleh beberapa cendekiawan muslim di Masjid Institut Teknologi Bandung (ITB) pada akhir tahun 1980an. Pendirian BMT ini didukung oleh Ikatan Cendekiawan Muslim Indonesia (ICMI), dan kemudian menjadi bagian sejarah dan cikal bakal berdirinya bank syariah di Indonesia pertama pada tahun 1992-an.

Spirit BMT pada dasarnya adalah memberikan kemudahan akses keuangan kepada masyarakat menengah ke bawah yang kurang mampu untuk mengakses lembaga keuangan perbankan. Di samping itu juga, BMT hadir sebagai gerakan akar rumput (grass-root movement) yang menyediakan alternatif pembiayaan platform kecil dan angsuran ringan. Gerakan ini juga menjadi solusi bagi masyarakat untuk lepas dari jeratan 'lintah darat' yang cenderung melahirkan masalah baru bagi nasabah pembiayaan. Dengan kata lain bahwa, BMT menjadi solusi masyarakat muslim untuk keluar dari jeratan riba yang dilarang oleh Islam.
Secara umum tujuan pendirian BMT adalah:

a. membantu meningkatkan dan mengembangkan potensi umat dalam program pengentasan kemiskinan;

b. memberikan sumbangan aktif terhadap upaya pemberdayaan dan peningkatan kesejahteraan umat;

c. menciptakan sumber pembiayaan dan penyediaan modal bagi anggota dengan prinsip syariah;

d. mengembangkan sikap hemat dan mendorong kegiatan gemar menabung bagi anggota;

e. menumbuh kembangkan usahausaha yang produktif dan sekaligus memberikan bimbingan dan konsultasi bagi anggota dibidang usahanya;

f. meningkatkan wawasan dan kesadaran umat tentang sistem dan pola perekonomian Islam; tujuh, membantu para pengusaha lemah untuk mendapatkan modal pinjaman, dan;

g. menjadi lembaga keuangan alternatif yang dapat menopang percepatan pertumbuhan ekonomi nasional (Ridwan, 2011).

Di samping tujuan tersebut di atas, BMT memilik prinsip yang menjadi landasan operasional, diantara-Nya; a. Keimanan dan ketakwaan kepada Allah SWT; b. Keterpaduan; c. Kekeluargaan; d. Kebersamaan; e. Kemandirian; f. Profesionalisme, dan; g. Istiqomah (Ridwan, 2011). Dengan demikian, BMT dapat dikatakan sebagai Lembaga Keuangan Mikro Syariah (LKMS) berbasis agama (Faith-Based Microfinance) (Mohamad Nazirwan, 2015).

Di samping spirit keagamaan, Baitul Mal wat Tamwil (BMT) juga menjadi sarana pendukung dalam rangka meningkatkan inklusi keuangan dan keterjangkauan (deep outreach) 
masyarakat terhadap lembaga keuangan. Tingkat keterjangkauan akses keuangan oleh masyarakat menjadi penting, sebab ia menjadi sumber injeksi modal dan keuangan bagi masyarakat. Saat ini Indonesia termasuk ke dalam negara yang memiliki tingkat inklusi keuangan terendah yaitu 49.53 persen. Angka tersebut berarti hampir 50 persen masyarakat Indonesia tidak memiliki akses kepada lembaga keuangan dan sebagian besarnya adalah muslim (Wulandari et al., 2016). Dalam rangka menjawab masalah tersebut, maka lahirnya Lembaga Keuangan Mikro (LKM) bertujuan untuk menghilangkan kendala dan memberikan akses sebesarbesarnya pada permodalan dan pembiayaan bagi masyarakat menengah ke bawah. Gerakan ini berkembang baik di beberapa negara dan LKM bertujuan melayani akses keuangan masyarakat miskin, seperti; Grameen Bank (Bangladesh); Development of Humane Action (DHAN) (Kalanjiam, India); Bank Desa (Amerika Latin dan Africa) (Khanam et al., 2018; Wulandari et al., 2016).

Dari penelitian Wulandari dkk tersebut, ditemukan bahwa BMT besar di pelbagai pulau di Indonesia secara khusus memiliki distingsi masing-masing bila dibandingkan dengan LKM konvensional. Ciri khas BMT di Indonesia dapat dilihat pada proses manajemen BMT, yaitu; prapembiayaan, pembiayaan, dan pascapembiayaan (Wulandari et al., 2016). Sedangkan kekhasan Grameen Bank adalah berbasis kepercayaan, sehingga ia tidak membebankan jaminan dan akad kontrak resmi kepada nasabah pembiayaan. DHAN memanfaatkan kepemimpinan masyarakat akar rumput membentuk Kelompok Swadaya (SHG) yang beranggotakan 10-15 orang dan memastikan kelompok bekerja dengan baik. Bank Desa Amerika Latin dan
Afrika memiliki ciri khas bahwa keterlibatan tim yang dibentuk Bank Desa sekitar 30-50 anggota yang menyediakan modal untuk pembiayaan satu anggota. Walaupun distingsi masing-masing LKM tersebut di atas berbeda-beda, akan tetapi mereka memiliki segmentasi yang sama dan mempunyai peran signifikan bagi masyarakat akar rumput. Melalui simplikasi program dan produk mereka membantu mengurangi tingkat kemiskinan dan meningkatkan pendapatan masyarakat, di samping itu LKM juga memberikan kemudahan dan keringanan dalam mendapatkan akses keuangan.

Dalam konteks Indonesia lembaga keuangan mikro berbasis swadaya masyarakat telah berkembang sejak awal pemerintahan orde baru. Lembaga ini dapat dibagi menjadi beberapa bentuk, yaitu Bank Desa dan Lumbung Desa yang muncul pada awal 1990-an di Jawa an Madura melalui supervisi Bank Rakyat Indonesia (BRI). Di samping itu terdapat juga Lembaga Perkreditan Desa (LPD) yang berkembang di provinsi Bali di bawah supervisi Bank Pembangunan Daerah (BPD). Kemudian, dalam rangka mempercepat mengentaskan kemiskinan, pemerintah Jawa Tengah pada awal tahun 1970-an menginisiasi terbentuknya Bank Kredit Kecamatan (BKK) di setiap tingkat kecamatan (Mohamad Nazirwan, 2015). Lembagalembaga tersebut di atas, memiliki tugas membantu meningkatkan taraf hidup masyarakat berpendapatan rendah dan tidak terakses oleh lembaga keuangan perbankan (un-bankable society).

\section{Financial Technology}

Financial Technology atau dikenal dengan istilah fintech muncul ketika konsorsium layanan teknologi keuangan yang diartikan sebagai memanfaatkan teknologi sebagai solusi keuangan 
(Arner et al., 2015). Dalam sejarah keuangan, fintech bukanlah hal baru, fintech secara umum dapat dibagi menjadi beberapa fase, yaitu: pertama, fintech 1.0 (1866-1987) dari analog ke digital. Di awal abad ke-19 perkembangan telegram, rel kereta api, kanal dan lainnya untuk mendukung globalisasi layanan informasi, transaksi, dan pembayaran keuangan. Kemudian dilanjutkan dengan peluncuran komputer oleh IBM, kalkulator keuangan oleh Texas Instrumen tahun 1967 dan kartu kredit oleh Dinner's Club 1950-an, Bank of America dan American Express tahun 1958. Inovasi fenomenal pada masa ini adalah diterbitkannya Automatic Teller Mechines (ATM) tahun 1967 oleh Barclays di United Kingdom (UK). Digitalisasi keuangan modern terjadi pada periode 1967-1987 (Arner et al., 2015).

Kedua, fintech 2.0 (1987-2008) perkembangan layanan keuangan digital tradisional. Pada periode ini ditandai dengan perhatian regulator pada risiko interkoneksi dan interseksi keuangan dengan sektor keuangan dengan diterbitkan regulasi terkait teknologi keuangan. Ketiga, Fintech 3.0 (2009Sekarang) berawal dari krisis global tahun 2008, periode ini ditandai dengan kompetisi baru dan keanekaragaman yang melahirkan peluang dan tantangan tersendiri. Keempat, finctech 3.5 untuk negara-negara berkembang, dimana mereka harus menyesuaikan diri dengan perkembangan teknologi.

Perkembangan infrastruktur teknologi, big data, analisis data, dan perangkat mobile memberikan ruang bagi perusahaan start-up untuk memotong mediasi dan alur perusahaan konvensional dengan memberikan distingsi, aktivitas spesifik yang sesuai, dan peranan pribadi (Lee \& Jae, 2018). Secara substansi revolusi fintech terjadi karena inovasi disrupsi yang memotong jalur, sehingga dapat memangkas biaya dan membuat keuangan perusahaan lebih efisien. Inovasi seperti ini menarik minat investor besar untuk menempatkan dana pada perusahaan tersebut dibanding dengan investasi pada perusahaan dengan sistem tradisional.

\section{METODE PENELITIAN}

Penelitian ini memanfaatkan menggunakan pendekatan deskriptif analisis dan paradigma interpretatif yang masuk dalam rumpun penelitian kualitatif. Metode kualitatif menjadi relevan dalam penelitian ini dikarenakan Baitul Mal wat Tamwil (BMT) memiliki segmentasi spesifik sebagaimana dijelaskan dan disaat bersamaan BMT menghadapi era disrupsi dimana terjadi beberapa pemotongan proses (cutting the procedure) serta teknologi berperan penting dalam transaksi keuangan saat ini. Kemudian data yang digunakan adalah data sekunder yang dipublikasi oleh pihak atau lembaga terpercaya, baik data dalam bentuk statistik, angka numerik, dokumentasi ataupun catatan historis.

Selanjutnya metode tersebut dilaksanakan dengan berbagai rangkaian teknis untuk mencapai hasil penelitian,(K. Yin, 2011; Rahardjo, 2017) diantara-Nya adalah:

1. Pertama, studi pustaka, pada bagian ini merupakan rentetan kegiatan penelitian yang berkaitan dengan pembacaan literatur, pengolahan data relevan dengan topik pembahasan.

2. Kedua, analisis data, peneliti dalam hal ini melakukan penelusuran baik dalam bentuk dokumentasi jurnal maupun laporan-laporan lembagalembaga terkait.

3. Ketiga, interpretasi (Creswell, 2012) rangkaian kegiatan ini dilakukan 
untuk menafsirkan gejala yang terjadi diantara kedua objek penelitian yaitu Baitul Mal wat Tamwil (BMT) dan perkembangan yang terjadi pada era revolusi industri 4.0.

4. Keempat, artikel ini melibatkan pandangan subjektivitas peneliti dalam melakukan prediksi ketahanan BMT pada saat Indonesia menikmati bonus demografi pada kisaran tahun 2030-2040.

Dari rangkaian teknis yang dilakukan di atas interpretasi unit analisis yang terdiri dari pertumbuhan BMT, dan demografi penduduk Indonesia dari data sekunder yang dirilis oleh BPS, pertumbuhan fintech di Indonesia yang dirilis oleh $\mathrm{BI}$ dan Kemenkeu yang kemudian dikaitkan dan dianalisis secara bersamaan untuk memunculkan gejalagejala yang berkaitan dengan tujuan artikel. Kemudian gejala (symthoms) tersebut diinterpretasi dalam rangka menarik kesimpulan dan rekomendasi yang dapat dilakukan untuk mengantisipasi terjadinya gejala yang muncul.

\section{HASIL DAN PEMBAHASAN}

\section{Distingsi Baitul Mal wat Tamwil}

Dengan tujuan dan prinsip yang dimiliki oleh BMT sebagaimana disebutkan sebelumnya, ia muncul menjadi salah satu solusi bagi negara untuk memperkecil tingkat kemiskinan dan meningkatkan perekonomian masyarakat akar rumput. Hal ini dikarenakan bahwa, segmentasi nasabah BMT sama sekali berbeda dengan lembaga keuangan lainnya. Oleh karena itu dengan jumlah penduduk miskin Indonesia saat ini mencapai angka 26.72 juta jiwa, Indonesia memerlukan keterlibatan semua elemen untuk terus mereduksi angka kemiskinan tersebut.
Akan tetapi, lebih dari pada masalah kemiskinan, BMT khususnya di bawah binaan Dompet Duafa (DD) di Yogyakarta memiliki spirit untuk mempertahankan keimanan seorang muslim ketika dilanda kemiskinan. Disaat yang bersamaan untuk melawan misionaris yang pada saat itu gencar melakukan kristenisasi pada masyarakat miskin. Oleh karena itu, BMT hadir untuk memberikan solusi nyata bagi masyarakat muslim miskin untuk berdaya, memiliki usaha dan berdiri di atas kaki sendiri (Mohamad Nazirwan, 2015). Spirit awalnya adalah dakwah yang diintegrasikan dengan lembaga filantropi sebenarnya telah tumbuh di awal pemerintahan Islam. Akan tetapi hal tersebut terlupakan oleh aktivis muslim, sehingga munculnya kristenisasi yang kemudian menjadi pemantik bagi para pemikir muslim untuk mengambil langkah nyata. Salah satunya upaya nyatanya adalah mendirikan BMT yang berkembang secara signifikan beberapa dekade ini.

Data yang dihimpun oleh
Perhimpunan menyatakan bahwa jumlah BMT di Indonesia saat ini mencapai 4000an lebih, walaupun yang terdaftar pada perhimpunan berjumlah 326 BMT per 2017. Tidak dapat dinafikan bahwa beberapa penelitian mengenai peran BMT, baik lembaga Mal maupun lembaga Tamwil memiliki peran yang signifikan dalam meningkatkan usaha, pendapatan, dan taraf hidup masyarakat akar rumput. Dengan demikian BMT dapat dikatakan masih memiliki peran penting pada masyarakat Indonesia.

Distingsi yang dimiliki oleh lembaga keuangan mikro syariah terlebih BMT adalah dapat menjangkau segmen pasar di pelosok-pelosok desa. Bagi BMT, Baitul Mal dapat memberikan pembiayaan kepada masyarakat miskin dengan skema qard\}ul al-h\}asan 
(pinjaman kebajikan) yang hanya mewajibkan nasabah pembiayaan untuk mengembalikan pokok pinjaman saja.

Di samping itu, Baitul Mal juga melakukan pendampingan usaha, pendampingan laporan keuangan dan pendampingan sosial keagamaan. Ketika menyalurkan pembiayaan dengan skema qard\}ul al-h\}asan, secara implisit Baitul Mal sudah mengetahui bahwa risiko skema tersebut, seperti nasabah tidak mengembalikan modal dengan utuh. Hal ini dikarenakan dana yang disalurkan tersebut bersumber dari dana Zakat, Infak, Sedekah dan Wakaf (ZISWAF) (Thoriquddin, 2014). Pada sisi Tamwil, BMT menjangkau segmentasi pasar dengan nominal pembiayaan yang relatif kecil, seperti pembiayaan nasabah dengan nominal di bawah 1 juta rupiah. Untuk mempermudah dan tidak memberatkan nasabah terkadang BMT menetapkan variasi jangka waktu pengembalian (harian, mingguan, bulanan) dan nominal angsuran yang terjangkau oleh nasabah.

Baitul Mal wat Tamwil (BMT) dalam aspek manajerial memiliki beberapa catatan. Sebagaimana diungkapkan oleh (Rusydiana \& Devi, 2013)yang menyebutkan bahwa setidaknya ada empat aspek penghambat perkembangan BMT yang dilihat dari aspek analisis proses networking (ANP) di Indonesia yaitu: sumber daya manusia; teknis; legalitas dan struktural, dan; pangsa pasar (Rusydiana \& Devi, 2013). Pernyataan tersebut setidaknya didukung oleh temuan pada BMT di Provinsi Banten bahwa dalam hal pembentukan harga dan manajemen sumber daya manusia ditemukan masih berbeda dengan syariah dan ketidakpahaman bagian administrasi, manajer, dan konsumen terkait kepatuhan Syariah (Muljadi et al., 2014). Pada konteks ini, di samping BMT menjadi salah satu pilar kebangkitan ekonomi akar rumput, akan tetapi disaat yang bersamaan BMT memiliki persoalan internal yang harus diselesaikan. Terlebih lagi masuk ke dalam era revolusi industri 4.0 saat ini yang menuntut kecepatan dan akurasi dalam hal pelayanan keuangan.

Akan tetapi, di tengah kejayaan eksistensi BMT di Indonesia beberapa tahun terakhir muncul revolusi dalam bidang keuangan, yaitu muncul era Revolusi Industri 4.0. Sehingga eksistensi BMT kembali mengalami dinamika dengan munculnya perusahaan-perusahaan teknologi yang juga bergerak dalam bidang keuangan. Perusahaan teknologi keuangan secara terang-terangan memutus beberapa jalur yang selama ini menjadi bagian dari operasional BMT. Seperti sistem pencatatan manual, di era fintech saat ini pekerjaan tersebut telah dilakukan oleh aplikator. Jangkauan nasabah pembiayaan, saat ini perusahaan fintech dapat menjangkau nasabah lebih banyak dari perusahaan keuangan konvensional. Dari sisi operasional, perusahaan fintech cenderung tidak membutuhkan kantor fisik yang banyak, sehingga inovasi ini memberikan dampak pada reduksi biaya operasional. Di lain pihak, lembaga keuangan konvensional khususnya BMT menanggung beban operasional yang cukup tinggi.

\section{Inovasi Financial Technology}

Beberapa tahun terakhir sejak diluncurkannya revolusi industri 4.0, pertumbuhan fintech menjadi fenomenal. Per triwulan pertama 2016 investasi pada perusahaan fintech mencapai 5.6 Milyar Dolar, naik sekitar 63 persen dari periode yang sama pada tahun sebelumnya (Lee \& Jae, 2018). Jumlah investasi tersebut tidak jauh berbeda dengan jumlah investasi pada perusahaan fintech di Indonesia yang mencapai 5.15 Milyar Dolar pada tahun 
2018. Meningkatkannya jumlah investasi pada perusahaan fintech saat ini tidak lepas dari diversifikasi model perusahaan yang tawarkan. Beberapa model bisnis yang ada dalam era disrupsi saat ini diantara-Nya adalah: Pembayaran; Manajemen Kekayaan; Crowdfunding; Pinjaman; Pasar Modal, dan; Asuransi (Lee \& Jae, 2018). Dengan demikian investor dan konsumen memiliki banyak pilihan dalam memilih platform yang mereka anggap menguntungkan.

Dalam sistem fintech, perusahaan tidak dapat berdiri sendiri, sehingga memerlukan beberapa entitas untuk mendukung operasionalnya. Dalam ekosistem fintech terdiri dari 5 elemen, yaitu: Fintech Start-Up, Technology Developers; Pemerintah; Konsumen Keuangan, dan; Institusi Keuangan Tradisional (Lee \& Jae, 2018). Dari lima elemen di atas yang menjadi core adalah perusahaan start-up. Lima entitas ini memiliki tugas masing-masing dan saling melengkapi satu dengan yang lainnya. Perusahaan start-up memainkan peran penting dalam hal inovasi dalam berbagai model fintech yang disebutkan di atas, kemudian menganalisis kebutuhan spesifik dan target konsumen.

Selanjutnya fungsi dari developer teknologi adalah menyediakan platform dari aspek kebutuhan sosial media, analisis big data, komputerisasi cloud, artifisial intelegence, telepon pintar, dan layanan bergerak. Sedangkan pemerintah memiliki peran menciptakan regulasi untuk menjaga stabilisasi lingkungan fintech. Konsumen merupakan sumber pendapatan bagi perusahaan fintech baik konsumen individu, usaha kecil maupun usaha menengah. Bagian terakhir adalah lembaga keuangan tradisional menjadi pendorong utama dalam siklus perusahaan fintech. Di samping itu, lembaga keuangan merupakan entitas yang paling terdampak akibat dari inovasi disrupsi, sebab perusahaan fintech dapat melakukan efisiensi yang signifikan dengan memangkas alur konvensional yang selama ini dilakukan.

\section{Resistensi Lembaga Keuangan Mikro Syariah Dalam Arus Global}

Industri Keuangan Bank (IKB), Industri Keuangan Non-Bank (IKNB), dan Lembaga Keuangan Mikro (LKM/Syariah) menjadi entitas paling terdampak terhadap inovasi disrupsi revolusi 4.0 sebagaimana disebutkan sebelumnya. Oleh karena itu, untuk mempertahankan eksistensinya di tengah masyarakat lembaga keuangan harus mengambil langkah-langkah penting. Diantara langkah tersebut adalah lembaga keuangan harus merubah arah kebijakan keuangan dengan menyesuaikan diri atau melakukan kolaborasi dengan perusahaan fintech.

Tidak hanya lembaga keuangan besar yang harus menyesuaikan diri, tapi juga lembaga keuangan mikro yang segmentasinya lebih spesifik. Kecepatan layanan, keterjangkauan yang lebih luas, dan akurasi menjadi keniscayaan lembaga keuangan mikro dalam pengelolaan bisnisnya. Salah satu inti dari era revolusi industri 4.0 saat ini adalah efisiensi, maka LKMS-BMT harus memangkas atau me-marger-kan jalur administratif tradisional menjadi pelayanan yang cepat. Di samping itu, kecepatan yang dilakukan harus juga mengedepankan akurasi dalam hal pencatatan dan laporan keuangan untuk kemudian menjaga kepercayaan konsumen. Selanjutnya adalah proses itu dihubungkan dengan dunia luar (connecting) dan interkoneksi (interconnecting) dengan lembagalembaga lain guna memperluas deepoutreach (M. Zuhro et al., 2019). 
Kelebihan BMT dibandingkan dengan perusahaan fintech diantara-Nya adalah BMT memiliki "rasa" yang tidak dimiliki oleh fintech. Terlebih bahwa, fintech menghilangkan tatap muka, memangkas tradisional administratif. Di samping itu, bahwa konsumen BMT saat ini adalah individu dan pengusaha kelas menengah ke bawah masih memerlukan pendampingan secara riil, tidak hanya dengan artificial intelligence. Komunikasi langsung menjadi penting untuk memberikan pemahaman yang komprehensif kepada konsumen. Di samping itu, tidak semua segmen umur dapat mengakses fintech, tercatat bahwa pengakses fintech didominasi oleh kaum milenial dengan rentang umur 18-34 tahun dibanyak negara.

Walaupun perusahaan fintech menggerus eksistensi institusi keuangan lain, akan tetapi fintech sendiri memiliki beberapa ancaman dalam operasionalnya, seperti: risiko manajemen investasi; manajemen konsumen; regulasi; risiko integrasi teknologi; risiko keamanan dan privasi, dan; risiko manajemen (Lee \& Jae, 2018). Dapat dilihat bahwa dari beberapa risiko yang dihadapi oleh perusahaan fintech, lima di antaranya terdapat pada internal perusahaan itu sendiri. Sedangkan risiko manajemen konsumen, setidaknya perusahaan dengan promosi dan sosialisasi tidak sepenuhnya dapat mencapai beberapa segmen konsumen. Seperti jumlah penduduk miskin dan penduduk usia lanjut. Penduduk miskin menjadi kendala perusahaan fintech dikarenakan keterbatasan akses kepada teknologi (lihat Table. 01). Selain itu, penduduk usia lanjut juga tidak memiliki akses yang disebabkan oleh perbedaan generasi.

BMT memiliki potensi ketahanan dalam arus global revolusi industri 4.0 dan akan tetap dibutuhkan oleh masyarakat selama orientasi segmen
BMT kepada pemberdayaan penduduk miskin. Hal ini ditandai bahwa konsumen dapat menjadi kendala bagi perusahaan fintech. Lambatnya program pemerintah dalam pengentasan kemiskinan, maka BMT masih memiliki segmen pasar untuk membantu pemerintah menyelesaikan masalah kemiskinan dengan program pemberdayaan. Akan tetapi, hal tersebut menjadi berbeda ketika nasabah BMT yang usia lanjut disubstitusi oleh grasi setelahnya. Oleh karena itu, BMT juga menghadapi ancaman dari aspek nasabah usia lanjut, seperti yang terlihat pada tabel. 04 berikut:

Tabel 4. Proyeksi Penduduk (ribu), Proyeksi Proporsi Penduduk Menurut Usia (persen/ribu), Proyeksi Laju Pertumbuhan Penduduk (persen)

\begin{tabular}{|c|c|c|c|c|}
\hline Items & $\mathbf{2 0 2 0}$ & $\mathbf{2 0 2 5}$ & $\mathbf{2 0 3 0}$ & $\mathbf{2 0 3 5}$ \\
\hline $\begin{array}{c}\text { Proyeksi Jumlah } \\
\text { Penduduk }\end{array}$ & $271,066.40$ & $284,829.00$ & $296,405.10$ & $305,652.40$ \\
\hline $\begin{array}{c}\text { Laju } \\
\text { Pertumbuhan }\end{array}$ & 1.19 & 1.00 & 0.80 & 0.62 \\
\hline $\begin{array}{c}\text { Usia 0-14 } \\
\text { Tahun }\end{array}$ & 26.10 & 24.60 & 22.90 & 21.50 \\
\cline { 2 - 5 } & $70,748.33$ & $70,067.93$ & $67,876.77$ & $65,715.27$ \\
\hline $\begin{array}{c}\text { Usia 15-64 } \\
\text { Tahun }\end{array}$ & 67.70 & 67.90 & 68.10 & 67.90 \\
\cline { 2 - 5 } & $183,511.95$ & $193,398.89$ & $201,851.87$ & $207,537.98$ \\
\hline Usia 60+ Tahun & 9.99 & 11.83 & 13.82 & 15.77 \\
\cline { 2 - 5 } & $27,079.53$ & $33,695.27$ & $40,963.18$ & $48,201.38$ \\
\hline Usia 65+ Tahun & 6.20 & 7.50 & 9.00 & 10.60 \\
\cline { 2 - 5 } & $16,806.12$ & $21,362,18$ & $26,676.46$ & $32,399.15$ \\
\hline \multirow{2}{*}{$\begin{array}{c}\text { Sumber: Data diolah dari Proyeksi Penduduk Indonesia 2010-2035, Katalog BPS } \\
\text { No: 2101018 (Statistik Demografi, 2013) }\end{array}$} \\
\hline
\end{tabular}

Saat ini konsumen fintech didominasi oleh generasi milenial dengan rentang umur antara 18-34 tahun. Proyeksi 2020 jumlah penduduk yang berusia 60 dan 65 tahun ke atas mencapai kurang lebih 15 persen (Statistik Demografi, 2013). Sedangkan pada tahun 2035 diproyeksikan persentase tersebut naik hampir mencapai dua kali lipat atau sekitar 25 persen lebih. Dengan asumsi bahwa generasi milenial yang mendominasi konsumen fintech saat ini, pada 15 tahun mendatang generasi milenial tersebut akan menggantikan posisi generasi yang saat ini berusia 65 tahun. Kemudian generasi usia 65 tahun ke atas akan memasuki usia uzur pada tahun 2035. Maka kondisi demografi Indonesia pada tahun 2035 akan diisi oleh generasi yang 
terbiasa dengan teknologi informasi. Dengan kata lain, apabila rasio inklusi keuangan di Indonesia pada tahun tersebut tinggi dan didukung oleh generasi milenial yang dekat dengan teknologi, maka eksistensi BMT sebagai LKMS yang menjangkau nasabah usia lanjut diproyeksikan akan digantikan oleh fintech.

\section{PENUTUP}

\section{Kesimpulan}

Financial Technology (fintech) pada era revolusi industri 4.0 dimana salah satu tugasnya adalah memotong jalur administratif pada lembaga keuangan tradisional. Sedangkan dilain pihak Baitul Mal wat Tamwil (BMT) sebagai Lembaga Keuangan Mikro Syariah (LKMS) memiliki mekanisme administratif yang relatif panjang yaitu berupa pendampingan konsumen prapembiayaan, proses pembiayaan, dan pasca-pembiayaan. Hal ini dikarenakan segmen pasar BMT adalah masyarakat yang tidak memiliki akses kepada lembaga keuangan perbankan (unbankable). Pada segmentasi tersebut setidaknya dapat dibagi menjadi dua bagian, yaitu masyarakat miskin atau menengah ke bawah dan masyarakat usia lanjut.

Eksistensi BMT akan terus berlanjut sebagai sarana pemberdayaan masyarakat miskin atau menengah ke bawah apabila upaya pemerintah lambat untuk menekan jumlah penduduk miskin. Akan tetapi, untuk segmen konsumen usia lanjut yang tidak terbiasa dengan teknologi, maka pada tahun 2035 penduduk usia lanjut di atas 65 tahun akan diisi oleh generasi milenial. Pada saat itu BMT diproyeksikan akan digantikan oleh fintech. Oleh karena itu, artikel ini merekomendasikan mendekati tahun tersebut BMT harus melakukan inovasi dengan integrasi dan interkoneksi dengan perusahaan fintech. Di samping itu juga BMT harus melakukan investasi pengetahuan (knowledge investment) bagi para pekerja (lazzolino \& Laise, 2018). Kemudian, penelitian ini perlu untuk dikembangkan bentuk-bentuk inovasi proses, produk dan manajemen nasabah. Di samping itu juga dari penelitian ini dapat dikembangkan model integrasi dan interkoneksi BMT dengan lembaga fintech.

\section{ACKNOWLEDGMENTS}

Artikel ini merupakan penelitian yang dilakukan secara mandiri. Artikel ini tugas mandiri mata kuliah Ekonomi Islam Interdisipliner yang diampu oleh oleh Bapak Dr. Ah. Ali Arifin, M. El pada Program Doktoral Ekonomi Syariah Pascasarjana Universitas Islam Negeri Sunan Ampel Surabaya tahun 2019.

\section{DAFTAR PUSTAKA}

Adnan, M. A., \& Ajija, S. R. (2015). The Efeectiveness of Baitul Maal Wat Tamwil in Reducing Poverty. H umanomics, 31(2), 160-182.

Arner, D. W., Barberis, J., \& Buckley, R. P. (2015). The Evolution of Fintech: A N ew Post-Crisis Paradigm?

Ayub, M. (2007). Understanding Islamic Finance. John Wiley \& Sons, Ltd.

Badan Pusat Statistik. (2018). Profil Kemiskinan M aret 2018.

Benthall, J. (1999). Financial Worship: The Quranic Injuction to Almsgiving. The Journal of the Royal Antropological Institute, 5(1), 27-42.

Creswell, J. W. (2012). Reseach Design: Pendekatan Kualitatif, Kuantitatif, dan Mixed (Edisi Keti). Pustaka Pelajar. 
Hardi, E. A. (2013). A nalisis Pemberdayaan $M$ asyarakat M uslim M iskin M elalui Q ardul Hasan (Studi kasus Program Baitul Maal BMT Beringharjo Yogyakarta Tahun 2013). Gadjah Mada University.

Hasanah, A., \& Yusuf, A. A. (2013). D eterminants of the Establishment of Islamic Micro Finance Institutions: The Case of Baitul M aal wa Tamwil (BM T) in Indonesia (No. 201308; Issue March).

Huda, N., \& Heykal, M. (2010). Lembaga Keuangan Islam: Tinjauan Teoritis dan Praktis. Kencana.

Iazzolino, G., \& Laise, D. (2018). Knowledge Worker Productivity: Is it Really Impossible to Measure It? M easuring Business Excellence, 22(4), 346-361. https:/ / doi.org/ 10.1108/ MBE-062018-0035

Indonesia, B. (n.d.). Ringkasan Eksekutif M emberdayakan Keuangan M ikro Syariah di Indonesia.

Jasa Keuangan, O. (2019a). D ompet Digital dan Fintech Lending di Indonesia Triwulan III 2018 [Goverment]. www.ojk.go.id

Jasa Keuangan, O. (2019b). Statistik Lembaga Keuangan Mikro (LKM) [Goverment]. www.ojk.go.id

Jumlah Akumulasi Pendanaan, Valuasi, dan Kunjungan pada perusahaan e-commerce.

(2019).

[Commercial].

D ataboks. www.databoks.co.id

K. Yin, R. (2011). Qualitative Research from Strart to Finish (112th ed.). The Guilford Press.

Khanam, D., Mohiuddin, M., Hoque, A., \& Weber, O. (2018). Financing Micro-entrepreneurs for Poverty Alleviation: A Performance Analysis of Microfinance Services
Offered by BRAC, ASA, and Proshika from Bangladesh. Jounal of Global Entrepreneurship Research, 8(27), 2-17.

Lee, I., \& Jae, Y. (2018). Fintech: Ecosystem, Business Models, Investment Decisions, and Challenges. Business Horizons, 61(1), 35-46. https:/ / doi.org/ 10.1016/ j.bushor. 2017.09.003

M. Dawam Rahardjo. (2015). A rsitektur Ekonomi Islam: M enuju Kesejahtraan Sosial. Mizan.

M. Zuhro, S., Syarifuddin, F., Sakti, A., \& T. Suryanti, E. (2019). Keuangan Publik dan Sosial Islam: Teori dan Praktik (Version 1, 1st ed.) [Computer software]. Rajawali Pers.

Mohamad Nazirwan. (2015). The Dynamic Role and Performance of Baitul Maal Wat Tamwil: Islamic Community Based Microfinance in Central Java. Victoria University.

Muljadi, Endraswati, H., \& Wahyuni, S. (2014). Operationalization of Shariah Marketing Mix in Baitul Maal wat Tamwil (BMT) at the Province of Banten, Indonesia. Riview of Integrative Business \& E conomics Research, 4(1), 41-48.

Rahardjo, M. (2017). Studi Kasus dalam Penelitian Kualitatif. UIN Malauna Malik Ibrahim.

Ridwan, M. (2011). M anajemen Baitul $M$ aal wat Tamwil (BMT) (3rd ed.). UII Press.

Rusydiana, A. S., \& Devi, A. (2013). Challenges in Developing Baitul Maal Wat Tamwiil (BMT) in Indonesia Using Analytic Network Process (ANP). Business and $M$ anagement $Q$ uaterly Review, $4(2), 51-62$. 
Statistik Demografi, S. (2013). Proyeksi Penduduk Indonesia: 2010-2035. Badan Pusat Statistik.

Thoriquddin, Moh. (2014). Pengelolaan Zakat Produktif di El-Zawa Universitas Islam Negeri (UIN) Maulana Malik Ibrahim Malang Perspektif $M$ aqa $>$ s\}i>d al-Sha>ri'ah Ibnu Ashu>r [Dissertation]. Universitas Islam Negeri Sunan Ampel Surabaya.
Wardani, H. K., \& Thoin, M. (2013). Pengelolaan Baitul Maal Dalam Meningkatkan Kesejahteraan Negara. Jurnal A kuntansi Dan Pajak, 14(01), 6-10.

Wulandari, P., Kassim, S., Sulung, L. A., Iwani, N., \& Surya Putri. (2016). Unique aspects of Islamic microfinance financing process: Experience of Baitul Maal Wa Tamwil in Indonesia. H umanomics, 32(3). 